\title{
Orchard Groundcover Management Impacts on Soil Physical Properties
}

\author{
Ian A. Merwin ${ }^{1}$ and Warren C. Stiles ${ }^{2}$ \\ Department of Fruit and Vegetable Science, Cornell University, Ithaca, NY 14853 \\ Harold M. van $\mathbf{E s}^{3}$ \\ Department of Soil, Crop and Atmospheric Sciences, Cornell University, Ithaca, NY 14853
}

\begin{abstract}
Additional index words. orchard floor management, weed control, herbicides, mulch, killed sod, Malus domestica, apple, soil conservation, sustainability

Abstract. This study was conducted to compare various orchard groundcover management systems (GMSs)—including a crownvetch "living mulch" (CNVCH), close-mowed (MWSOD) and chemically growth-regulated (GRSOD) sodgrasses, pre-emergence (NDPQT) and two widths of post-emergence (GLY1.5 and GLY2.5) herbicides, hay-straw mulch (STMCH), and monthly rototillage (tilled)_during the first 6 years in a newly established apple (Malus domestica Borkh.) planting. Mean soil water potential at 5 to $35 \mathrm{~cm}$ deep varied substantially among treatments each summer, and treatment $\times$ year interactions were observed. During most growing seasons from 1986 to 1991, soil water availability trends were STMCH > NDPQT > GLY2.5 > GLY1.5 > tilled > GRSOD > MWSOD > CNVCH. Soil organic matter content increased under STMCH, CNVCH, and MWSOD and decreased under NDPQT and tilled treatments. Water infiltration and saturated hydraulic conductivity after 4 years were lower under NDPQT and tilled, and soil under STMCH and GRSOD retained more water per unit volume at applied pressures approximating field water capacity. Mid-summer soil temperatures at $5 \mathrm{~cm}$ deep were highest $(25$ to $28 \mathrm{C}$ ) in tilled and NDPQT plots, intermediate (22 to 24C) under GRSOD, and lowest (16 to 20C) under CNVCH and STMCH. These observations indicate that long-term soil fertility and orchard productivity may be diminished under pre-emergence herbicides and mechanical cultivation in comparison with certain other GMSs.
\end{abstract}

Herbicides are widely used to suppress competing surface vegetation beneath fruit trees, and many studies have shown that chemical weed control is economical and beneficial for establishment and early fruit production of newly planted orchards (Atkinson and White, 1981; Haynes, 1980; Welker and Glenn, 1988). After more than 4 decades of herbicide use, residues of these and other agrichemicals have been detected in many domestic water supplies and major surface water systems, which has instigated an interest in alternative weed control methods (National Research Council, 1989). Serious questions have also been raised about the long-term impacts of tillage, herbicides, and other orchard groundcover management systems (GMSs) on soil fertility, organic matter, tilth, and erosion (Atkinson and Herbert, 1979; Elmore, 1989; Glenn and Welker, 1989; Hipps and Samuelson, 1991; Merwin, 1990). Several comprehensive reviews assessing the relative advantages and disadvantages of various GMSs have emphasized the need for additional information on the physiological, economic and edaphic impacts of alternative orchard GMSs (Haynes, 1980; Hogue and Neilsen, 1987; Skroch and Shribbs, 1986). In 1985, we initiated a long-term orchard study to evaluate the impacts of various GMSs on soil physical and chemical conditions, apple tree physiology and productivity, and the apple pest complex. The effects of GMSs on apple tree physiology and yield are reported elsewhere (Merwin and Stiles, 1994). This paper summarizes the impacts of different GMSs on edaphic characteristics such as soil

Received for publication 22 June 1992. Accepted for publication 25 June 1993. Cornell Univ. Dept. of Fruit and Vegetable Science paper no. 28. This research was supported in part by USDA-CSRS Hatch Project NY(C)-142409. We gratefully acknowledge the assistance of Michael Moracco, Eve Minson, and Robert Schindelbeck in conducting this research and the critical reviews of the manuscript by Marvin P. Pritts and H. Christian Wien. The cost of publishing this paper was defrayed in part by the payment of page charges. Under postal regulations, this paper therefore must be hereby marked advertisement solely to indicate this fact. ${ }^{1}$ Assistant professor.

${ }^{2}$ Professor.

${ }^{3}$ Assistant professor. water retention and availability, bulk density, pore size distribution, temperatures, soil organic matter content, groundcover biomass, and apple root distribution.

\section{Materials and Methods}

Experimental design. The experiment was established in a former apple orchard at Ithaca, N.Y., which had been maintained for hay production and without trees during the previous 8 years. The soil is a glacial lacustrine Hudson silty-clay loam (mixed mesic Udic Hapludalf) with textural proportions of 7\% sand, 71\% silt, and $22 \%$ clay, and at the beginning of this study mean topsoil organic matter content was $53 \mathrm{~g} \cdot \mathrm{kg}^{-1}$ and $\mathrm{pH}$ was 5.8 . An illuvial layer 35 to $40 \mathrm{~cm}$ deep restricts internal soil drainage, but surface drainage is facilitated by $2 \%$ to $6 \%$ slopes. In 1985 , subsoil drainage lines were installed throughout the site and dolomitic lime was applied at $12 \mathrm{Mg} \cdot \mathrm{ha}^{-1}$ and thoroughly incorporated into the subsoil; the site was not fumigated before replanting. In Apr. 1985, a 70:30 mixture of 'Elka' perennial ryegrass (Lolium perenne L.) and 'Ensylva' creeping red fescue (Festuca rubra L.) was seeded at $50 \mathrm{~kg} \cdot \mathrm{ha}^{-1}$ over the entire site with an 'Astro' oat (Avena sativa L.) nurse-crop. In Apr. 1986, alternate rows of 'Empire' and 'Jonagold' apple on MM.111 rootstock were planted in augered holes spaced $3 \mathrm{~m}$ within rows and $6 \mathrm{~m}$ across sod alleyways. GMS treatments were randomly assigned to strips centered on the tree rows in experimental units of eight adjacent trees in a blocked design (split by apple cultivars) with six replications of the following: 1) $\mathrm{CNVCH}-\mathrm{a} 2.5$-m-wide "living mulch" leguminous groundcover of 'Penngift' crown vetch (Coronilla varia L.); 2) GLY1.5a 1.5-m-wide killed-sod strip provided by annual applications of $\mathrm{N}$-(phosphonomethyl)glycine (glyphosate) at a rate of $2 \mathrm{~kg}$ a.i. per treated hectare in May and July; 3) GLY2.5-a 2.5-m-wide killedsod strip, provided as above; 4) NDPQT - a 2.5-m-wide strip of bare ground provided by annual applications of 4-chloro-5(methylamino)-2-(3-(trifluoromethyl)phenyl)-3(2H)-pyridazinone 
(norflurazon), $N$ '”-(3,4-dichlorophenyl)- $N, N$-dimethyl-urea (diuron), and 1,1'-dimethyl-4,4'-bipyridinium ion (paraquat), all tankmixed at $3.0,2.5$, and $0.5 \mathrm{~kg}$ a.i. per treated hectare, respectively, in May; 5) MWSOD - the sodgrass mixture of red fescue and perennial ryegrass, mowed to maintain a height of 6 to $10 \mathrm{~cm}$; $)$ GRSOD - a 2.5-m-wide strip of the same sodgrass mixture, treated annually in May and July 1986-89 with the growth suppressant 1,2-dihydro-3, 6-pyridazinedione (maleic hydrazide) applied at 5 $\mathrm{kg}$ a.i. per treated hectare and the broadleaf selective herbicide 2,4dichlorophenoxyacetic acid (2,4-D amine) applied at $1.5 \mathrm{~kg}$ a.i. per treated hectare; beginning in 1990 a sublethal rate of glyphosate $(0.2 \mathrm{~kg}$ a.i. per treated hectare) was substituted for the previous GRSOD suppressant treatment in these plots; 7) STMCH-a 2.5m-wide hay-straw mulch strip $15 \mathrm{~cm}$ deep (30 kg/tree), renewed annually in May; and 8) tilled-a 2.5-m-wide clean-cultivated strip provided by rototilling to $10 \mathrm{~cm}$ deep monthly, May through August each year. Data were subjected to analysis of variance and mean separation when appropriate, based on protected least significant differences using the SuperANOVA statistical program (Abacus Concepts, Berkeley, Calif.). The treatment $\times$ year interaction was significant in most years, but the treatment $\times$ cultivar interaction was not $(P<0.05)$. For most of the statistical analyses, data for the two apple cultivars were therefore pooled and treatment effects were determined within years.

Determinations of soil water and other physical conditions. The frost-free growing season in Ithaca averages 155 days, from mid-May to mid-October, but we were not able to measure soil water availability during this entire time span every year. We measured soil water tension weekly from June through Sept. 1986 and 1987, at 15 and $30 \mathrm{~cm}$ deep with two tensiometers placed between trees at the center of each plot. Beginning in 1988, we used a neutron-source hydroprobe (model 503-DR; CPNCorp., Pacheco, Calif.) to evaluate soil water content. Measurements of the hydrogen-atom density 15 and $30 \mathrm{~cm}$ deep around a single, permanently placed aluminum access tube equidistant between trees near the center of each plot were converted to volumetric soil water content using prior calibration data from simultaneously extracted soil cores collected adjacent to the access tubes on two sampling dates, one with wet and another with dry soil conditions. Volumetric soil water-content values $\left(\varnothing_{\mathrm{v}}\right)$ were subsequently converted to kiloPascals $(\mathrm{kPa})$ of soil water tension (SWT) using a regression

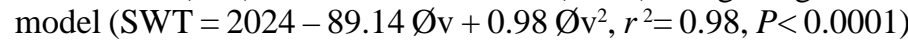
developed by pressure-plate moisture-release analyses (Richards, 1954) of soil cores taken in Sept. 1989 from each of the plots. Monthly precipitation and pan-evaporation records were obtained from a weather station located $\approx 1 \mathrm{~km}$ from the orchard. Midday soil temperatures $5 \mathrm{~cm}$ deep in nonshaded areas of each plot were measured weekly from May to Sept. 1989 using a portable thermistor probe.

In mid-Aug. 1991, intact soil cores were removed in Coile-type noncompacting aluminum sleeves $(7.8 \times 8.0 \mathrm{~cm})$ from each plot 1 to 9 and 11 to $19 \mathrm{~cm}$ deep and analyzed for soil bulk density and moisture release characteristics. To allow completion of all measurements on a single sampling date, we excluded one of the glyphosate (GLY1.5) and sodgrass (MWSOD) treatments from these sixth year analyses. Soil macro-, meso- and micropore size distributions were estimated by measuring water release from intact soil cores under incrementally increased pressures of 0 to 40 $\mathrm{kPa}$. Sorptivity, saturated hydraulic conductivity, and cumulative infiltration were measured at two locations in each plot in July 1989 and Aug. 1991, using 18-cm-diameter rings and Marriotttype permeators modified after Reynolds and Elrich (1990). Cumulative infiltration in 1991 was also estimated in only two replications of the six treatments, using sprinklers to simulate rainfall at $20 \mathrm{~cm} \cdot \mathrm{h}^{-1}$ within a 70 -cm-diameter single-ring infiltrometer driven $8 \mathrm{~cm}$ into the soil. Apple roots were counted in mid-July 1991, $\approx 1 \mathrm{~m}$ distant from the end tree in each of the 12 rows, in a $30 \mathrm{~cm}^{2} \times 80 \mathrm{~cm}$ deep soil volume, by superimposing a plexiglass grid of $15 \times 15$ squares of $4 \mathrm{~cm}^{2}$ at successive horizontal planes downward in hand-excavated pits next to a backhoe trench. Apple roots greater than $1 \mathrm{~mm}$ in diameter observed within each of the 225 transect grids were counted at intervals from $0-1,1-5,5-$ $10,10-15,15-20$, and then every $10 \mathrm{~cm}$ to $80 \mathrm{~cm}$ deep in the soil profile. Soil organic matter content was determined by loss on ignition at $500 \mathrm{C}$ for $2 \mathrm{~h}$. Groundcover fresh weight biomass per square meter was estimated by harvesting all above-ground vegetation during late Aug. 1989 in a $0.5-\mathrm{m}^{2}$ subplot within each replicate. The area of each plot covered by surface vegetation was estimated by visual projection.

\section{Results}

Soil water availability. Soil water tensions in the upper $35 \mathrm{~cm}$ of the soil profile differed among groundcover treatments in every year of this study. The orchard was not irrigated, and during several relatively dry months in 1986 and 1987 (Fig. 1), SWT values in all but the STMCH plots exceeded the $85 \mathrm{kPa}$ maximum operational range of the tensiometers used to monitor water availability. Since SWT data for these 2 years were noncontinuous, weekly values were ranked and subjected to a Kruskal-Wallis nonparametric analysis of variance, which indicated that SWT was highest in MWSOD, GRSOD, and CNVCH plots during 1986 and 1987, and lowest in STMCH plots ( $P<0.05$, data not shown).

Trends in soil water content during 1988 to 1991 were complex and varied from year to year as well as among treatments during each growing season (Fig. 2 A-D). SWT was highest in early and mid-summer under $\mathrm{CNVCH}$ and MWSOD during most years. When the crownvetch was suppressed by mowing in May and July 1991, SWT decreased in this treatment relative to MWSOD (Fig. 2D). Soil in the MWSOD plots was drier than in GRSOD during several droughty periods of 1988, 1989, and 1991 (Fig. 2). For several periods of frequent rainfall in 1989 (days 177 to 193) and 1990 (days 163 to 176), GRSOD and MWSOD plots were actually wetter than many other treatments except STMCH (Fig. 2 B-C). SWT values in the NDPQT and GLY herbicide treatments were similar during most years, and not significantly higher in the 1.5$\mathrm{m}$ compared with the $2.5-\mathrm{m}$-wide glyphosate plots. SWT was usually lower in the STMCH than in other treatments during the early summer months, especially during droughts in June 1988 and 1991. The mulched plots dried out substantially during late sum-

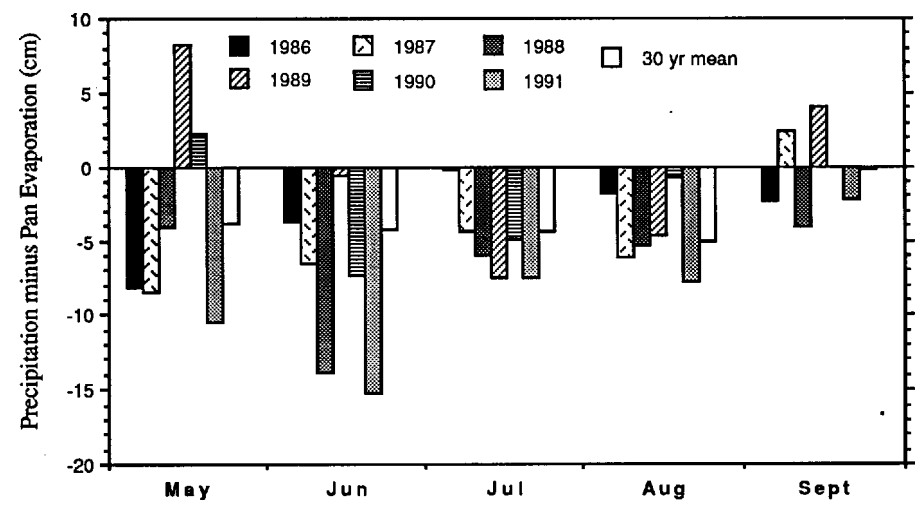

Fig. 1. Monthly precipitation minus pan evaporation for growing seasons of 1986 to 1991 , with 30 year means at Ithaca, N.Y., presented for reference. 


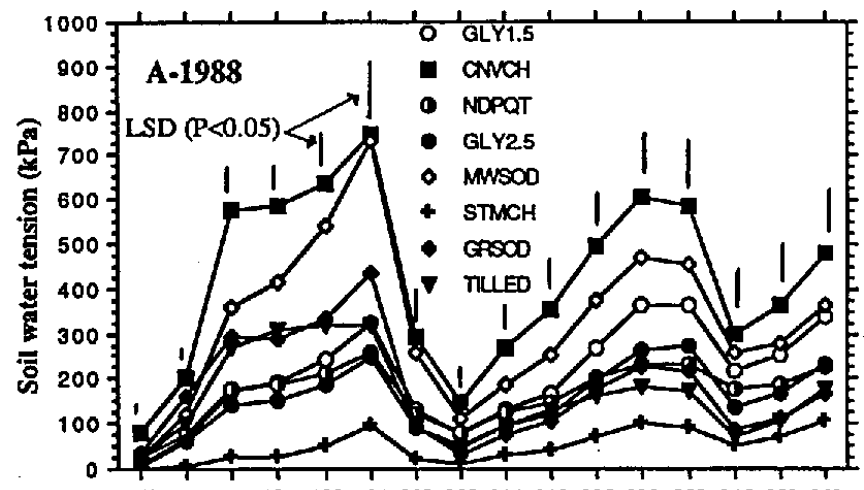

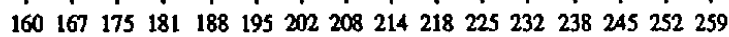

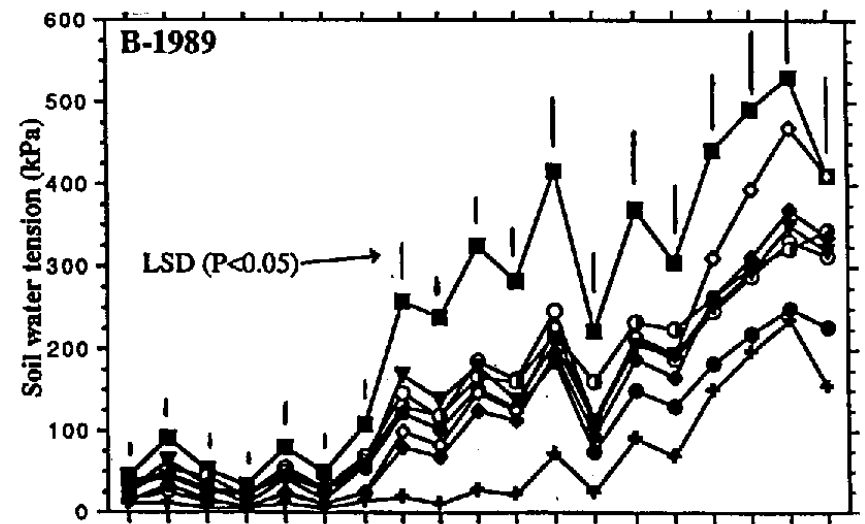

139146151158163170177184193198205212219229233242249255260
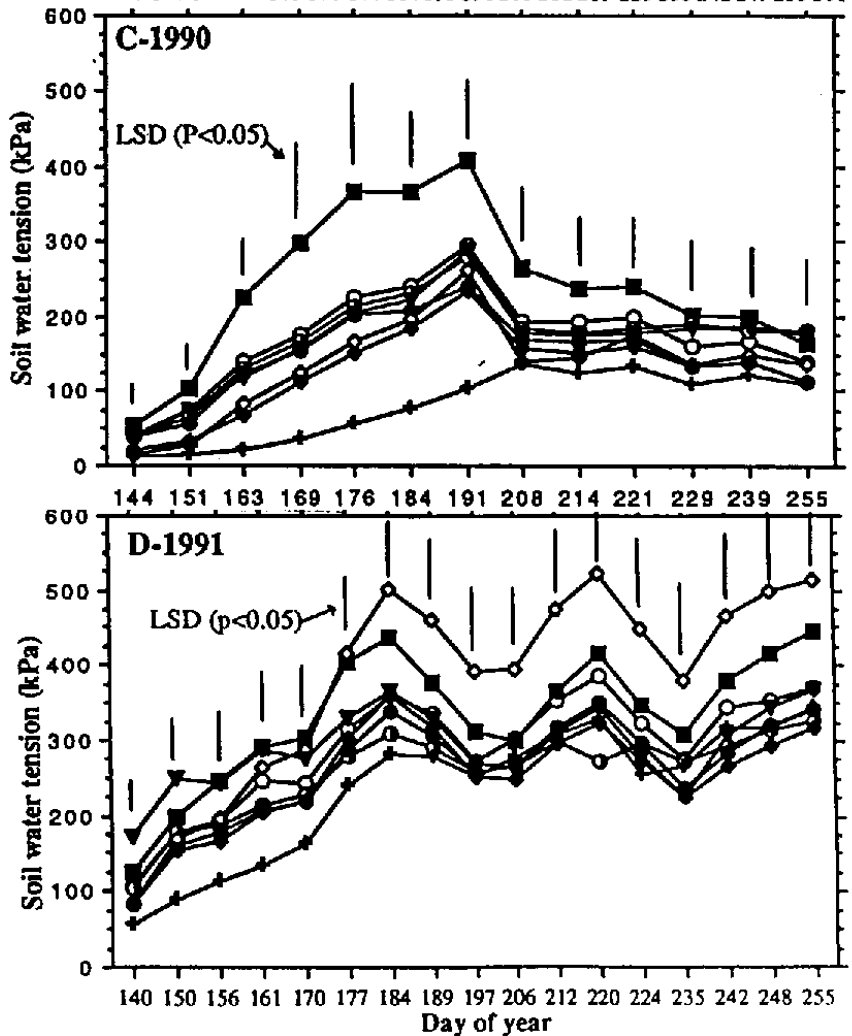

Fig. 2. Soil water tension (kPa) averaged at 10 to $35 \mathrm{~cm}$ deep for observations at approximately weekly intervals during the growing seasons of 1988 to 1991. LSD values $(P<0.05)$ are for the means of six replicates at each sampling date, each year.

mer each year as quackgrass (Agropyron repens L.) weed populations increased. Soil in the tilled plots was generally drier than in the herbicide or STMCH plots, but more moist than in the sodgrass or $\mathrm{CNVCH}$ plots.

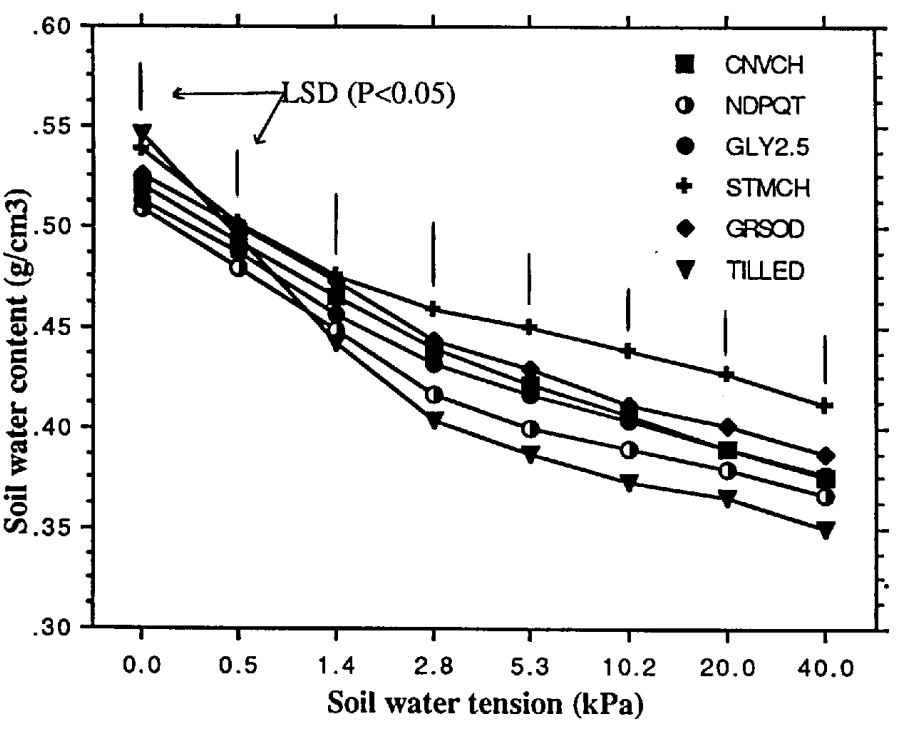

Fig. 3. Volumetric soil water content $\left(\mathrm{g} \cdot \mathrm{cm}^{-3}\right)$ at applied pressures of 0 to $40 \mathrm{kPa}$ in soil cores extracted from 1 to $9 \mathrm{~cm}$ deep after 6 years in each GMS treatment. LSD values $(P<0.05)$ are for means of six observations per treatment at each applied pressure.

After 6 years under different GMSs, soil water retention characteristics from 0 to $40 \mathrm{kPa}$ (field capacity range for this soil) were also affected by treatments (Fig. 3). In 1989, after 4 years, our soil moisture release analyses indicated no significant differences among treatments (data not shown), but by 1991, the NDPQT and tilled soil retained less water per unit volume than GRSOD and STMCH at applied pressures from 2.8 to $40 \mathrm{kPa}$. Total soil pore volumes (calculated from bulk density values) were equivalent in all treatments (Table 1), but more of the total pore volume was in the larger pore fractions (> 385 and 50 to $385 \mu \mathrm{m}$ ) in tilled topsoil. Porosity in GRSOD and CNVCH subsoil was greater in the 15 to $50-\mu \mathrm{m}$ mesopore fraction relative to tilled and NDPQT plots. The $<15-\mu \mathrm{m}$ micropore fraction was lowest in tilled, intermediate in NDPQT and GLY plots, and higher in STMCH topsoil.

Water sorptivity, cumulative infiltration, and saturated hydraulic conductivity in the topsoil profile were also affected by treatments (Table 2). Under relatively wet soil conditions immediately following cultivation in 1989, sorptivity and cumulative infiltration of water were greatest in tilled and lowest in STMCH and NDPQT plots. Under drier conditions in 1991, when a surface crust had formed 3 weeks after cultivation of the tilled plots, cumulative infiltration was much reduced in tilled and NDPQT plots relative to the other treatments (Table 2).

After 4 years, the bare soil in NDPQT plots had developed a dense surface crust that impeded water sorptivity, cumulative infiltration, and saturated hydraulic conductivity in 1989. Considerably more soil erosion was observed in NDPQT than any other treatment. Deep shrinkage cracks opened in all but the STMCH plots during mid-summer each year, and we attempted to avoid placing infiltrometer rings over visible cracks that would greatly enhance preferential water flow through channels and bypass the surrounding soil matrix. These cracks were filled by siltation of eroding soil in the NDPQT plots and were disrupted by cultivation in tilled plots, but remained open to rapid percolation of rainwater under the other treatments.

Soil physical conditions. Soil organic matter content in the upper $20 \mathrm{~cm}$ profile increased by $9 \mathrm{~g} \cdot \mathrm{kg}^{-1}$ after 5 years under STMCH, remained relatively unchanged under CNVCH, GLY, MWSOD, and GRSOD, but decreased in tilled and NDPQT plots 
Table 1. Soil bulk density, and percent of total soil porosity in macro-, meso- and micropore size categories, at 1 to 9 and 11 to $19 \mathrm{~cm}$ deep in an orchard soil after 6 years under different groundcover management systems (GMSs).

\begin{tabular}{|c|c|c|c|c|c|c|c|c|c|c|}
\hline \multirow[b]{4}{*}{$\mathrm{GMS}^{\mathrm{x}}$} & \multicolumn{10}{|c|}{ Pore size distribution (percent of total soil pore volume) } \\
\hline & \multirow{2}{*}{\multicolumn{2}{|c|}{$\begin{array}{c}\text { Bulk density } \\
\left(\mathrm{g} \cdot \mathrm{cm}^{-3}\right)\end{array}$}} & \multirow{2}{*}{\multicolumn{2}{|c|}{$\begin{array}{l}\text { Macropores } \\
(\%>385 \mu \mathrm{m})^{\mathrm{z}}\end{array}$}} & \multicolumn{4}{|c|}{ Mesopores } & \multirow{2}{*}{\multicolumn{2}{|c|}{$\begin{array}{l}\text { Micropores } \\
(\%<15 \mu \mathrm{m})\end{array}$}} \\
\hline & & & & & \multicolumn{2}{|c|}{$(\% 50$ to $385 \mu \mathrm{m})$} & \multicolumn{2}{|c|}{$(\% 15 \text { to } 50 \mu \mathrm{m})^{\mathrm{y}}$} & & \\
\hline & $(1-9 \mathrm{~cm})$ & $(11-19 \mathrm{~cm})$ & $(1-9 \mathrm{~cm})$ & $(11-19 \mathrm{~cm})$ & $(1-9 \mathrm{~cm})$ & $(11-19 \mathrm{~cm})$ & $(1-9 \mathrm{~cm})$ & $(11-19 \mathrm{~cm})$ & $(1-9 \mathrm{~cm})$ & $(11-19 \mathrm{~cm})$ \\
\hline$\overline{\text { GLY2.5 }}$ & 1.34 & 1.34 & 2.6 & 3.0 & 8.2 & 8.5 & 2.8 & 2.7 & 37.2 & 36.6 \\
\hline $\mathrm{CNVCH}$ & 1.30 & 1.34 & 2.9 & 2.9 & 8.0 & 7.3 & 3.3 & 3.2 & 38.3 & 37.3 \\
\hline NDPQT & 1.32 & 1.37 & 2.6 & 2.0 & 9.2 & 8.2 & 2.7 & 1.7 & 37.0 & 38.0 \\
\hline GRSOD & 1.25 & 1.27 & 3.0 & 2.9 & 8.2 & 7.5 & 3.2 & 3.2 & 39.7 & 40.1 \\
\hline STMCH & 1.25 & 1.34 & 3.7 & 2.8 & 8.0 & 7.2 & 2.0 & 2.2 & 40.4 & 38.4 \\
\hline Tilled & 1.24 & 1.41 & 5.0 & 2.5 & 14.3 & 7.3 & 3.0 & 1.7 & 32.3 & 37.6 \\
\hline $\operatorname{LSD}_{(P \leq 0.50)}{ }^{\mathrm{w}}$ & NS & NS & 1.5 & NS & 2.6 & NS & NS & 1.2 & 3.1 & NS \\
\hline
\end{tabular}

${ }^{\mathrm{z}}$ Macropore volume determined by water release in saturated soil after $3 \mathrm{~h}$ without applied pressure.

${ }^{\mathrm{y}}$ Mesopore volume determined by water release from soil cores at 0 to $2.8 \mathrm{kPa}$ (for 50 -to 385 - $\mu \mathrm{m}$ pores), 2.8 to $10.0 \mathrm{kPa}$ applied pressures (for 15 -to $50-\mu \mathrm{m}$ pores), and remainder of total soil pore volume in micropore size range $(<15 \mu \mathrm{m}$ diameter $)$.

xTreatment abbreviations: GLY2.5 = glyphosate post-emergence herbicide; CNVCH = crownvetch "living mulch"; NDPQT = norflurazon + diuron + paraquat pre-emergence herbicides; GRSOD = growth-regulated sodgrass; STMCH = hay-straw mulch; tilled = monthly tillage.

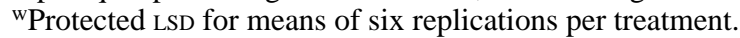

(Table 3). Above-ground biomass (not including trees) at the end of the 1989 growing season was greatest in $\mathrm{CNVCH}$, least in the GLY, and intermediate in other treatments. Both GLY treatments developed a pervasive and persistent thin layer of surface moss during the course of this study, which explains their relatively high proportion of vegetative ground coverage but low above-ground biomass. Although most of the soil in NDPQT plots remained bare, dense patches of broadleaf perennial weeds-primarily milkweed (Asclepias syriaca L.) and ground ivy (Glechoma hederacea L.) in two replicates contributed to the deceptively large mean value for standing biomass in this treatment. Nearly all of the surface vegetation in STMCH plots consisted of quackgrass at the time of sampling. Much of the biomass and surface coverage in the tilled plots was within the mid-row strip beneath the trees, where weeds were difficult to suppress effectively with cultivation. Aboveground biomass in MWSOD and GRSOD plots was similar at sampling time, but these values represent the total cumulative biomass for an entire growing season in the GRSOD plots as opposed to recent regrowth following the last of five seasonal mowings in the MWSOD treatment.

Mid-day soil temperatures $5 \mathrm{~cm}$ deep were higher from May to Oct. 1989 in treatments without surface vegetation, averaging 16 to $20 \mathrm{C}$ under $\mathrm{CNVCH}$ and STMCH, 22 to $24 \mathrm{C}$ under GRSOD, and 25 to $28 \mathrm{C}$ under GLY2.5, NDPQT, and tilled treatments (Fig. 4). During overcast days (days 166, 202, and 257) there were fewer differences among treatments. Soil temperatures were lowest under CNVCH, GRSOD, and STMCH treatments both early and late in the growing season. Few differences were observed in soil temperatures $15 \mathrm{~cm}$ deep under different GMS treatments (data not shown). Soil temperatures were not recorded during subsequent years because relative trends were expected to remain similar (Hogue and Neilsen, 1987). The differences in apple root distribution, counted at sequential intervals from 0 to $80 \mathrm{~cm}$ deep in our excavations under each GMS and apple cultivar, were not significantly different at $P<0.05$ (Fig. 5). Because of the time and labor requirements of this procedure, we could only complete two sample replications for each treatment. We present the root count data despite that limitation, because they facilitate the interpretation of edaphic trends. More roots were counted under STMCH and fewer under $\mathrm{CNVCH}$ treatments, and fewer roots were observed near the soil surface in NDPQT and tilled plots.

\section{Discussion}

Soil moisture. There are surprisingly few reports about the soil water requirements of apple trees and the relative water demands of orchard groundcovers (Atkinson and White, 1981; Haise and Hagan, 1967; Kenworthy, 1949; Stiles, 1982). In our study, apple shoot growth was greatest in plots with seasonal SWT means of 150 to $175 \mathrm{kPa}$ (Merwin, 1990), and substantial reductions of tree growth were associated with higher SWT in the crownvetch and sodgrass treatments. Soil water availability was generally greatest under straw mulch, intermediate in the three herbicide treatments, and least under the $\mathrm{CNVCH}$ and sodgrass GMS; however, treatment $\times$ year interactions occurred every year $(P<0.05)$ as the weather varied. There appeared to be diminishing differences in SWT among treatments during comparable droughts in 1988 and 1991 (Figs. 2 A vs. D). Since tree canopy volume and crop load were greater in the herbicide and STMCH treatments from 1987 onward (Merwin and Stiles, 1994), increasing soil water consumption by the larger trees may have counteracted the decreased water consumption by the few weeds in these treatments. As in other reports (Hogue and Neilsen, 1987; Tisdall et al., 1984), straw mulch provided better soil moisture conservation than chemical or mechanical weed control practices.

The groundcover in MWSOD and GRSOD plots consisted primarily $(59 \% \pm 8.5 \%$ and $83 \% \pm 4.2 \%$, respectively) of the originally seeded mixture 5 years after establishment. The two species cultivars in this mixture ('Elka' perennial ryegrass and 'Ensylva' red fescue) were selected because they are low-vigor, cool-season grasses that hypothetically might be less competitive than other groundcovers (Butler, 1986). Although the mixed sod of these two grass species depleted soil water less than crownvetch, soil was usually drier under both sodgrass treatments than other GMSs. The two growth-suppressant treatments evaluated in the GRSOD plots-10\% of the minimum recommended herbicidal rate of glyphosate $(0.2 \mathrm{~kg}$ a.i./treated ha) and maleic hydrazide plus 2,4-D amine-substantially reduced soil water consumption in 3 of 4 years compared with frequent mowing in the MWSOD plots. The apparent reduction in grass evapotranspiration and increase in water infiltration under GRSOD treatments actually led to lower SWT under this treatment than most other treatments during several wetter periods of the 1989 and 1991 growing seasons. 
Table 2. Soil water sorptivity, cumulative infiltration, and saturated hydraulic conductivity under rainfall simulation at $20 \mathrm{~cm} \cdot \mathrm{h}^{-1}$ in an orchard soil after 4 (1989) and 6 (1991) years under different groundcover management systems (GMSs).

\begin{tabular}{|c|c|c|c|c|c|}
\hline \multirow[b]{2}{*}{ GMS } & \multirow{2}{*}{$\begin{array}{c}\begin{array}{c}\text { Sorptivity } \\
\text { z } \\
\left(\mathrm{cm} \cdot \mathrm{s}^{-1}\right)\end{array} \\
1989\end{array}$} & \multicolumn{2}{|c|}{$\begin{array}{l}\text { Cumulative } \\
\text { infiltration }^{\mathrm{y}} \\
\quad\left(\mathrm{cm} \cdot \mathrm{h}^{-1}\right)\end{array}$} & \multicolumn{2}{|c|}{$\begin{array}{l}\text { Hydraulic } \\
\text { conductivity } \\
\left(\mathrm{cm} \cdot \mathrm{h}^{-1}\right)\end{array}$} \\
\hline & & 1989 & 1991 & 1989 & 1991 \\
\hline NDPQT & 0.9 & 15 & 19 & 8 & 18 \\
\hline STMCH & 0.7 & 24 & 301 & 20 & 26 \\
\hline GRSOD & 7.4 & 109 & 263 & 52 & 15 \\
\hline GLY2.5 & 9.0 & 143 & 367 & 92 & 32 \\
\hline $\mathrm{CNVCH}$ & 8.1 & 94 & 575 & 48 & 89 \\
\hline Tilled & 18.2 & 176 & 71 & 60 & 31 \\
\hline $\left.\operatorname{LSD}_{(P \leq 0.05)}\right)^{\mathrm{x}}$ & 6.2 & 14 & 42 & 59 & NS \\
\hline
\end{tabular}

$\overline{{ }^{\mathrm{z}} \text { Sorptivity calculated by regression of cumulative infiltration vs. square }}$ root of time $(600 \mathrm{sec})$.

${ }^{y}$ Cumulative infiltration for 1989 and 1991 measured within 15- and 70$\mathrm{cm}$-diameter infiltrometer rings, under moist and dry soil conditions, for six and two replications, respectively.

xProtected LSD for means of six replications per treatment.

Table 3. Topsoil organic matter ( 0 to $20 \mathrm{~cm}$ ) and change in organic matter content (in parentheses) from 1986 to 1990, fresh weight biomass of groundcover vegetation per square meter in late Aug. 1989, and average percent projective vegetation coverage of plot surfaces (excluding apple trees) during late Aug. in 1987 to 1989 in different groundcover management systems (GMSs).

\begin{tabular}{lccc}
\hline \hline GMS & $\begin{array}{c}\text { Topsoil } \\
\text { organic matter } \\
{\left[\mathrm{g} \cdot \mathrm{kg}^{-1}( \pm \text { change })\right]}\end{array}$ & $\begin{array}{c}\text { Groundcover } \\
\text { biomass } \\
\left(\mathrm{g} \cdot \mathrm{m}^{-2}\right)\end{array}$ & $\begin{array}{c}\text { Projective } \\
\text { ground-coverage } \\
(\% \text { plot surface })\end{array}$ \\
\hline Tilled & $4.5(-1.0)$ & 1286 & 53.4 \\
NDPQT & $4.8(-0.7)$ & 664 & 24.2 \\
GLY1.5 & $4.9(-0.2)$ & 200 & 63.4 \\
GLY2.5 & $5.0(-0.3)$ & 239 & 66.9 \\
CNVCH & $5.2(+0.1)$ & 2150 & 99.2 \\
GRSOD & $5.3(0.0)$ & 922 & 98.3 \\
MWSOD & $5.6(+0.1)$ & 902 & 99.5 \\
STMCH & $6.2(+0.9)$ & 875 & 69.8 \\
LSD $_{(P \leq 0.05)}{ }^{\mathrm{x}}$ & $1.0(1.0)$ & 372 & 9.7 \\
\hline${ }^{2} \mathrm{GrOH}$ &
\end{tabular}

$\overline{{ }^{\mathrm{z}} \text { Groundcover fresh weight biomass determined by harvesting of } 0.5-\mathrm{m}^{2}}$ sample quadrats in each plot, during late Aug. 1989.

yProjective coverage of plots determined by visual estimate of the percent of plot surfaces covered by living groundcover vegetation, not including tree canopies.

${ }^{x}$ Protected LSD for means of six replicates.

These observations confirm other reports (Atkinson and Petts, 1978; Stott, 1976) that chemical growth suppressants may offer a practical alternative to frequent mowing or cultivation for grass management in orchards. The relatively drier soil in NDPQT compared with sodgrass, STMCH, and GLY plots on many days during 1989 and 1990 (both wet summers) might have been caused by the reduced infiltration and capture of summer rainfall in the bare-soil of this pre-emergence herbicide treatment, as surface aggregate structure in this treatment deteriorated and slaked (Hillel, 1980). More surface runoff erosion was observed after 6 years in both the NDPQT and tilled treatments compared with the other treatments in which living or residual surface vegetation provided protection and stabilization of the soil surface (Russell, 1971).

Soil physical conditions. We observed fewer definitive impacts of GMS treatments on soil physical conditions than those reported by other researchers (Atkinson and White, 1981; Glenn and Welker, 1989; Haynes, 1981; Tisdall et al., 1984). Soil porosity, organic matter content, and water infiltration remained relatively satisfactory in all GMSs at this orchard after 6 years. These results may be related to the prior decades of continuous herbaceous and grass groundcover in this orchard, which resulted in excellent soil tilth and organic matter content at the outset of this study. Nevertheless, the diminished organic matter content and infiltration rates after 6 years in NDPQT plots indicate a loss in soil tilth and rainfall capture, which could limit long-term orchard productivity (Hipps and Samuelson, 1991). A similar problem was evident in the tilled treatment, and after 6 years the soil surface in this treatment had subsided by several centimeters compared with the adjacent sod alley. The temporary increase in macro-porosity following a recent cultivation improved water percolation in the 1989 infiltrations (Table 2). When the same tests were repeated in 1991, 3 weeks after cultivation, when rainfall had repacked and crusted the soil surface, water infiltration was considerably reduced in the tilled plots. Since these plots are not cultivated during the fall, winter, or spring, an increased potential for surface runoff and erosion exists in orchards under this GMS. The lower proportion of soil pores $<15$ $\mu \mathrm{m}$ in diameter observed under herbicide and tilled treatments could also diminish the retention of plant-available water between field water capacity and the permanent wilting point in these GMSs.

The "killed sod" system described by Welker and Glenn (1988) was most closely approximated by the GLY treatments in our study. In pre-emergence herbicide (NDPQT) plots, the killed residues of the initial grasscover decomposed during the first summer (1986), leaving the soil surface largely uncovered for the remainder of the study. In contrast, killed weed residues and a thin surface moss persisted in the GLY plots, providing a protective cover for the soil surface with minimal weed competition for soil water reserves.

We attributed the observed differences in soil temperatures to greater exposure of bare soil to sunlight in the herbicide and tillage treatments (Hillel, 1980). Temperatures $5 \mathrm{~cm}$ deep in all treatments remained within the ranges reported as suitable for MM.111 rootstocks (Carlson, 1965). However, the uppermost centimeter of soil in NDPQT plots probably exceeded the $28 \mathrm{C}$ measured at $5 \mathrm{~cm}$ on hot sunny days, which might explain the scarcity of roots observed immediately below the surface in that treatment. The increased proliferation of apple roots at lower soil levels beneath competing grass roots and at upper levels in herbicide treatments, which has been reported by others (Atkinson and White, 1981), was not evident in our study. Moreover, when treatment means were pooled and total root counts per tree were correlated with trunk cross-sectional area, the correlation coefficient was not significant at $P<0.05$, because the ratio of trunk size to total root count was relatively higher for trees in herbicide plots. We speculate that the relatively large proportion of tree roots $30 \mathrm{~cm}$ deep in all treatments was caused by a seasonally high water table and the restrictive effect of the dense illuvial layer below that depth in this orchard. As in other studies comparing mulch with herbicides, cultivation, or grass swards, the distribution and density of apple roots appeared to be affected by GMS, but the high variability of tree root distribution and the difficulty in obtaining adequate numbers of replicate samples made our determination of root response to GMS inconclusive (Atkinson, 1980; Haynes, 1981; White and Holloway, 1967).

There is much controversy about the sustainability of conventional production practices for fruit as well as other horticultural crops (York, 1991). However, most agriculturists would agree that 


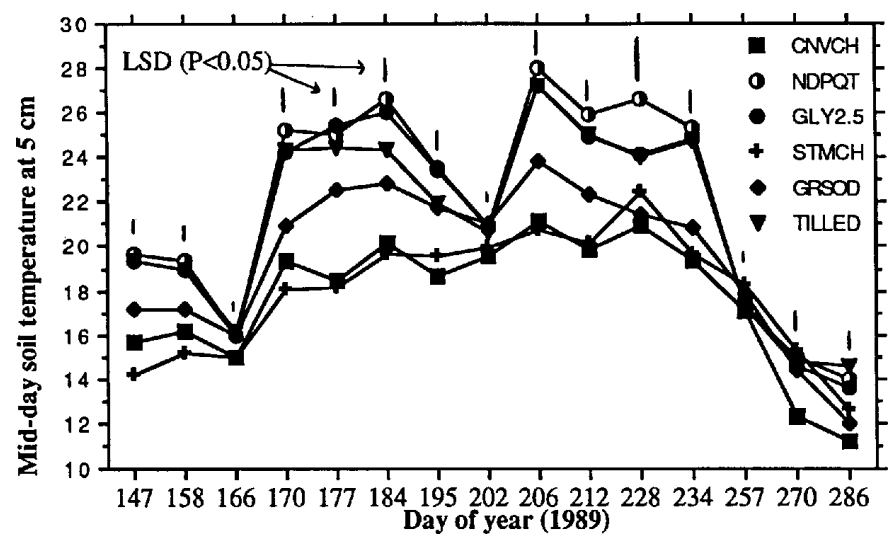

Fig. 4. Midday soil temperatures at $5 \mathrm{~cm}$ deep during the 1989 growing season, at approximately weekly intervals. LSD values $(P<0.05)$ are for the means of six replicates at each sampling date, each year.

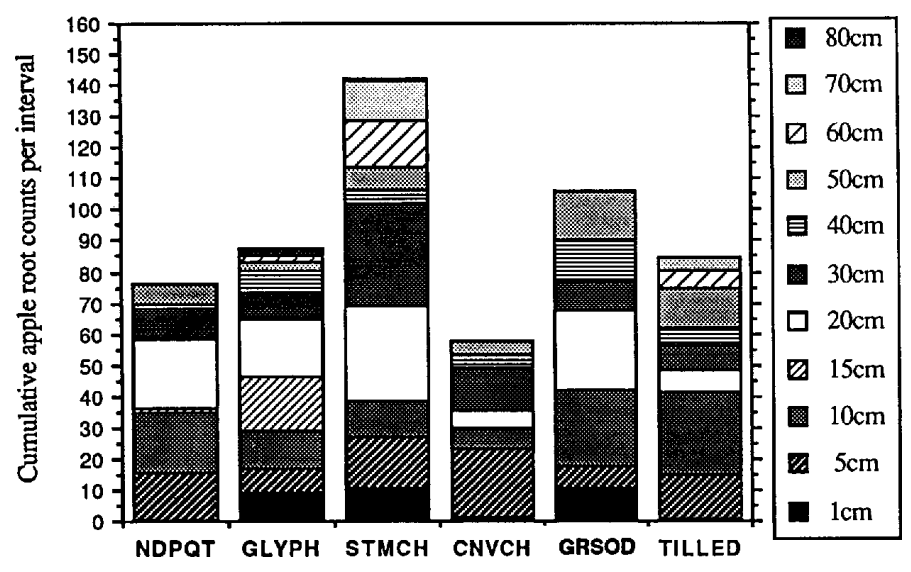

Fig. 5. Apple root counts in $30 \times 30 \mathrm{~cm}$ square grid at consecutive intervals from surface to $80 \mathrm{~cm}$ deep in mid-July 1991 . Values are means of two observations per treatment, and were not significantly different $(P<0.05)$.

the long-term conservation of topsoil structure, organic matter, and fertility must be included in any meaningful definition of sustainable agriculture. The relative impacts of different orchard GMSs on these critical soil conditions in our study were most evident in soil organic matter and water conservation or availability. Soil organic matter increased or held constant under straw mulch, sodgrass, crownvetch, and post-emergence glyphosate treatments, but decreased under pre-emergence herbicides and tillage. Soil water and organic matter were best conserved under straw mulch, which might appear to be the optimal orchard GMS in our study. Unfortunately, the straw mulch was prohibitively expensive, and tree mortality was highest (37\% after 4 years) under this treatment due to serious problems with phytophthora root rot and meadow voles (Microtus pennsylvanicus) (Merwin, 1991; Merwin et al., 1992). The crownvetch "living mulch" and mowed sodgrass depleted soil water substantially more than other treatments, and probably caused drought stress in the fruit

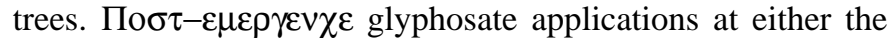
conventional herbicidal rates or sublethal growth-suppressant rates appeared to provide adequate soil water conservation and surface vegetation coverage to protect the soil from destructive weathering and to sustain soil tilth as well as orchard productivity.

\section{Literature Cited}

Atkinson, D. 1980. The distribution and effectiveness of the roots of tree crops, p. 424-490. In: J. Janick (ed.). Horticultural reviews. vol. 2. Avi Publishers, Westport, Conn.

Atkinson, D. and R.F. Herbert. 1979. A review of the long-term effects of herbicides: Effects on the soil with particular reference to orchard crops. Ann. Applied Biol. 91:125-146.

Atkinson, D. and S.C. Petts. 1978. Effect of the chemical management of orchard swards on the use of water and mineral nutrients. Proc. 1978 British Crop Protection Conf. p. 223-230.

Atkinson, D. and G.C. White. 1981. The effects of weeds and weed control on temperate fruit orchards and their environment, p. 415-428. In: J.M. Thresh (ed.). Pests, pathogens and vegetation: The role of weeds and wild plants in the ecology of crop pests and diseases. Pittman, London.

Butler, J.D. 1986. Grass interplanting in horticulture cropping systems. HortScience 21:394-397.

Carlson, R.F. 1965. Responses of Malling Merton clones and Delicious seedlings to different root temperatures. Proc. Amer. Soc. Hort. Sci. 86:41-45.

Elmore, C.L. 1989. Vegetation management systems in almond orchards. California Agr. 43(4)16-22.

Glenn, D.M. and W.V. Welker. 1989. Orchard soil management systems influence rainfall infiltration. J. Amer. Soc. Hort. Sci. 114:10-14.

Haise, H.R. and R.M. Hagan. 1967. Soil, plant and evaporative measurements as criteria for scheduling irrigation, p. 577-604. In: R.M. Hagan, H.R. Haise, and T.W. Edminster (eds.). Irrigation of agricultural lands. Amer. Soc. Agron., Madison, Wis.

Haynes, R.J. 1980. Influence of soil management practice on the orchard agro-ecosystem. Agroecosystems 6:3-32.

Haynes, R.J. 1981. Effects of soil management practices on soil physical properties, earthworm population and tree root distribution in a commercial apple orchard. Soil Tillage Res. 1:269-280.

Hillel, D. 1980. Soil structure and aggregation, p. 93-117. In: Fundamentals of soil physics. Academic Press, San Diego.

Hipps, N.A. and T.J. Samuelson. 1991. Effects of long-term herbicide use, irrigation and nitrogen fertiliser on soil fertility in an apple orchard. J. Sci. Food Agri. 55:377-387.

Hogue, E.J. and G.H. Neilsen. 1987. Orchard floor vegetation management, p. 377-430. In: J. Janick (ed.). Horticultural reviews. vol. 9. Avi Publishers, Westport, Conn.

Kenworthy, A.L. 1949. Soil moisture and growth of apple trees. Proc. Amer. Soc. Hort. Sci. 54:29-39.

Klute, A. 1986. Methods of soil analysis. 2nd ed. Amer. Soc. Agron., Madison, Wis.

Merwin, I.A. 1990. Alternatives in orchard ground-cover management: Effects on apple tree growth and nutrition, soil physical conditions, phytophthora root disease, and relative weed species abundance. $\mathrm{PhD}$ Diss., Cornell Univ., Ithaca, N.Y.

Merwin, I.A. 1991. Alternatives in orchard groundcover management. Proc. 136th Annu. Meeting New York State Hort. Soc. 136:71-84.

Merwin, I.A., W.F. Wilcox, and W.C. Stiles. 1992. Influence of orchard ground cover management on the development of phytophthora crown and root rots of apple. Plant Dis. 76:199-205.

Merwin, I.A. and W.C. Stiles. 1994. Orchard groundcover management system impacts on apple tree growth and yield, and nutrient availability and uptake. J. Amer. Soc. Hort. Sci. 119:209-215.

National Research Council. 1989. Problems in U.S. agriculture, p 89-134. In: Alternative agriculture. Rpt Natl. Res. Council, Natl. Acad. of Sci. Press, Washington, D.C.

Reynolds, W.D. and D.E. Elrich. 1990. Ponded infiltration from a single ring: I. Analysis of steady flow. Soil Sci. Soc. Amer. J. 54:1233-1241.

Richards, L.A. 1954. Diagnosis and improvement of alkaline and alkali soils. U.S. Dept. of Agr. Hdbk. no. 60.

Russell, E.W. 1971. Soil structure: Its maintenance and improvement. J. Soil Sci. 22:137-151.

Skroch, W.A. and J.M. Shribbs. 1986. Orchard floor management: An overview. HortScience 21:390-394.

Stiles, W.C. 1982. Soil management practices which influence soil moisture and irrigation, p. 153-169. In: R.B. Tukey (ed.). Proceedings of the short course on tree fruit irrigation. Wash. State Univ., Pullman.

Stott, K.G. 1976. The effects of competition from ground covers on apple 
vigor and yield. Ann. Applied Biol. 83:327-330.

Tisdall, J.M., K.A. Olson, and P. Willoughby. 1984. Soil structural management and production in a non-cultivated peach orchard. Soil Tillage Res. 4:165-174.

White, G.C. and R.C. Holloway. 1967. The influence of simazine or a straw mulch on the establishment of apple trees in grassed down or cultivated soil. J. Hort. Sci. 42:377-389.

Welker W.V. and D.M. Glenn. 1988. Growth responses of young peach trees and changes in soil characteristics with sod and conventional planting systems. J. Amer. Soc. Hort. Sci. 143:652-656.

Welker, W.V. and D.M. Glenn. 1989. Sod proximity influences the growth and yield of young peach trees. J. Amer. Soc. Hort. Sci. 114:856-859.

York, Jr., E.T. 1991. Agricultural sustainability and its implications to the horticultural profession and the ability to meet global food needs. HortScience 26:1252-1256. 